JIA (Jurnal Ilmiah Akuntansi) • Vol. 5, No. 1, Hal: 45-60 • Juni 2020

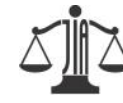

\title{
Internal Locus of Control dan Efek Computer Anxiety pada Kinerja Karyawan Keuangan
}

\author{
Ni Made Rai Juniariani*, Komang Adi Kurniawan Saputra \\ Universitas Warmadewa, Jalan Terompong No. 24, Denpasar, Bali, Indonesia \\ *(raijuniari@gmail.com)
}

\section{Riwayat Artikel: \\ Tanggal diajukan: \\ 23 Desember 2019 \\ Tanggal diterima: \\ 13 Mei 2020 \\ Tanggal dipublikasi daring: 25 Juni 2020}

Kata kunci: computer anxiety; internal locus of control; kinerja karyawan keuangan

\section{Pengutipan:}

Juniariani, N. M. R. \& Saputra, K. A. K. (2020). Internal Locus of Control dan Efek Computer Anxiety pada Kinerja Karyawan Keuangan JIA (Jurnal Ilmiah Akuntansi), 5 (1), 45-60

Keywords: computer anxiety; financial employee performance; internal locus of control

\begin{abstract}
ABSTRAK
Penelitian ini bertujuan untuk menganalisis pengaruh computer anxiety pada kinerja karyawan keuangan dan untuk menganalisis peran internal locus of control dalam memoderasi pengaruh computer anxiety pada kinerja karyawan keuangan. Penelitian ini diharapkan mampu memberikan pertimbangan bagi Lembaga Perkreditan Desa (LPD) agar secara rutin memberikan pelatihan baik pelatihan komputer maupun pelatihan kepribadian kepada karyawannya sehingga karyawannya cakap dalam mengoperasikan program komputer keuangan yang digunakan dan mempunyai kepribadian yang baik serta mampu memberikan pelayanan yang maksimal kepada masyarakat Data yang digunakan adalah data primer yang berupa jawaban kuesioner yang didistribusikan pada karyawan LPD yang ada di Kota Denpasar. Teknik analisis yang digunakan untuk menjawab hipotesis penelitian adalah Moderated Regression Analysis (MRA). Hasil pengujian hipotesis menunjukkan computer anxiety berpengaruh negatif pada kinerja karyawan keuangan, dan internal locus of control memperlemah pengaruh computer anxiety pada kinerja karyawan keuangan.
\end{abstract}

ABSTRACT
This study aims to analyze the influence of computer
anxiety on financial employee performance and to analyze
whether the internal locus of control moderate the
influence of computer anxiety on financial employee
performance. This research is expected to be able to give
consideration to Lembaga Perkreditan Desa (LPD) to
routinely provide training in both computer training and
personality training to their employees so that their
employees are capable of operating financial computer
programs that are used and have good personalities and
are able to provide maximum services to the public. The
data used are primary data in the form of answers to
questionnaires distributed to LPD employees in the Kota
Denpasar. The analysis technique used to answer the
research hypothesis is Moderated Regression Analysis
(MRA). Hypothesis testing results show that computer
anxiety has a negative effect on financial employee
performance, and internal locus of control weakens the
influence of computer anxiety on financial employee
performance.


PENDAHULUAN

\begin{tabular}{lcr}
\multicolumn{1}{c}{ Teknologi } & informasi & selalu \\
berkembang & seiring & dengan \\
kebutuhan para & praktisi & dalam \\
menjalankan & \multicolumn{2}{c}{ kegiatannya. }
\end{tabular}

Perkembangan teknologi informasi mampu menyediakan informasi yang up to date dan dapat dipercaya. Dalam perkembangannya sistem informasi ini sendiri identik dengan perkembangan pada sistem komputer. Sistem informasi berbasis komputer juga mengalami perkembangan yang signifikan hampir pada semua bidang. Hal ini menyebabkan terjadinya banyak perubahan, dimana seseorang mampu menyelesaikan pekerjaan dengan cepat, efektif dan efisien karena tenaga kerja diganti dengan menggunakan sistem komputerisasi.

Teknologi informasi khususnya teknologi komputer memberikan banyak keuntungan dan kemudahan dalam dunia bisnis. Penggunaan teknologi komputer pada suatu perusahaan sangat mempengaruhi kinerja masing-masing karyawannya. Kinerja adalah hasil kerja baik secara kualitas maupun kuantitas yang dicapai oleh seseorang dalam melaksanakan tugas sesuai tanggung jawab yang diberikan (Juniariani, Pradnyanitasari, \& Priliandani, 2018). Kinerja individual karyawan penting untuk diperhatikan karena sangat mempengaruhi

keberhasilan

perusahaan. Perkembangan teknologi komputer sangat membantu kinerja individual karyawan dalam mengerjakan berbagai tanggung jawabnya di dalam perusahaan. Mulai dari menghitung, mengolah data, ataupun mencari data dan informasi melalui internet (Saputra, Sujana, \& Tama, 2018).

Perkembangan teknologi yang sangat pesat tidak akan terlaksana dengan baik tanpa dukungan dari pengguna teknologi itu sendiri. Teknologi yang baik harus didukung dengan sumber daya manusia yang terampil untuk mengoperasikannya. Namun sering kali perkembangan teknologi dihadapkan pada suatu kondisi dimana kemampuan organisasi dalam penerapan teknologi tidak sesuai dengan kemampuan individu di dalam organisasi tersebut untuk mengaplikasikannya, hal itu disebabkan karena setiap individu memberikan respons yang berbeda seperti menerima maupun menolak dengan hal-hal yang bersifat baru (Parasara, 2014). Penolakan ini mungkin disebabkan oleh kegelisahan yang mendalam atau ketakutan yang berlebihan terhadap perkembangan teknologi komputer yang sering disebut computerphobia dan bahkan terkadang menimbulkan tekanan (stress) (Ali \& Fadila, 2008). 
Ada beberapa orang menganggap perubahan ini sebagai anxiety (kecemasan), namun ada pula yang menganggap perubahan adalah suatu tantangan (Ali \& Fadila, 2008). Sebagian orang merasa khawatir dengan adanya komputer karena mereka belum banyak menguasai teknologi komputer, sehingga mereka belum bisa mendapat manfaat dengan kehadiran komputer. Computer anxiety merupakan kecendrungan seseorang menjadi khawatir atau takut terhadap pemakaian komputer pada saat ini maupun dimasa mendatang (Yudha \& Ramantha, 2014). Harimurti dan Astuti (2016) dalam penelitiannya menyatakan bahwa computer anxiety berpengaruh negatif pada penguasaan komputer. Semakin tinggi computer anxiety maka tingkat keahlian mahasiswa menggunakan komputer akan semakin menurun (Harimurti \& Astuti, 2016).

Kecemasan dalam menggunakan komputer (computer anxiety) akan mempengaruhi kinerja individual karyawan. Dengan adanya kondisi tersebut tentu akan sangat merugikan perusahaan tempat karyawan tersebut bekerja (Wahyudi \& Widianto, 2019). Oleh karena itu keyakinan individu akan kemampuan dirinya harus ditingkatkan supaya kinerja individu tersebut juga semakin meningkat. Kinerja karyawan sangat erat kaitannya dengan kepribadian karyawan. Salah satu aspek dari kepribadian karyawan adalah locus of control. Locus of control adalah sejauh mana seseorang percaya bahwa ia mampu mengendalikan faktor-faktor yang mempengaruhinya (Sanjiwani \& Wisadha, 2016). Individu yang memiliki kepercayaan terhadap dirinya sendiri dan menerima tanggung jawab atas segala tindakan yang dilakukan (internal locus of control) akan dapat meningkatkan kinerja individu tersebut (Saputra, 2012). Individu dengan kecenderungan internal locus of control akan memiliki keyakinan yang tinggi pada kemampuannya dalam hal ini menggunakan program komputer sehingga kecemasannya dalam mengoperasikan komputer dapat diatasi dan kinerjanya akan semakin meningkat.

\section{Harimurti dan Astuti (2016)} menyatakan bahwa internal locus of control memoderasi pengaruh computer anxiety dalam penggunaan software akuntansi terhadap keahlian pemakai komputer pada mahasiswa. Interaksi antara kecemasan berkomputer dengan internal locus of control akan meningkatkan keahlian mahasiswa dalam menggunakan komputer. 
Terdapat ketidakkonsistenan hasil dari penelitian sebelumnya dan mengingat pentingnya penguasaan teknologi komputer khususnya komputer keuangan maka peneliti tertarik untuk melakukan penelitian dengan responden karyawan Lembaga Perkreditan Desa (LPD) Kota Denpasar yang mengoperasikan program keuangan.

LPD adalah badan usaha milik desa pakraman yang merupakan unit operasional yang berfungsi sebagai wadah kekayaan milik desa pakraman, yang berupa uang atau surat-surat berharga (Peraturan Daerah Provinsi Bali Nomor 2 tahun 1988). Berdasarkan pada tujuan dan bidang usaha yang dilakukan, LPD pada dasarnya adalah lembaga keuangan yang mempunyai aktivitas yang hampir sama dengan bank karena LPD menerima simpanan, memberikan pinjaman, dan memberikan jasa-jasa lain, yang diarahkan pada usaha-usaha peningkatan taraf hidup krama desa.

Perkembangan LPD dalam kondisi persaingan yang semakin ketat menyebabkan aktivitas operasional dan manajerial LPD menjadi semakin kompleks Volume transaksi semakin besar, kompleksitas pengolahan transaksi semakin tinggi, serta adanya tuntutan untuk menyediakan pelaporan keuangan dengan lebih cepat dan akurat, menyebabkan LPD perlu mengembangkan sistem informasi berbasis komputer. Di samping itu, adanya perkembangan sistem informasi di bidang perbankan, serta pelayanan yang lebih cepat pada nasabah juga merupakan alasan perlunya LPD mengembangkan sistem informasi berbasis komputer (Saputra \& Kurniawan, 2017).

Berdasarkan latar belakang diatas perumusan masalah dalam penelitian ini adalah apakah computer anxiety berpengaruh pada kinerja karyawan keuangan LPD Kota Denpasar dan apakah internal locus of control memoderasi pengaruh computer anxiety pada kinerja karyawan keuangan LPD Kota Denpasar. Penelitian dilakukan di Kota Denpasar karena Kota Denpasar merupakan central perekonomian di Bali dan khususnya untuk LPD di Kota Denpasar, Pemerintah Kota Denpasar mentargetkan kedepannya seluruh LPD yang ada di Kota Denpasar dikelola secara maksimal berbasis digitalisasi agar pelayanan kepada masyarakat lebih maksimal (Patria, 2019). Untuk mendukung program tersebut, LPD harus menyiapkan sumber daya manusianya sehingga program dari Pemerintah Kota Denpasar terlaksana dengan baik. 
Tujuan dilakukan penelitian ini adalah untuk menjelaskan bahwa kinerja karyawan dengan realitas sebenarnya dilapangan dipengaruhi oleh bagaimana sikap dan keyakinan karyawan dalam menggunakan teknologi yang ada. Penelitian ini diharapkan mampu memberikan pertimbangan bagi LPD agar secara rutin memberikan pelatihan baik pelatihan komputer maupun pelatihan kepribadian kepada karyawannya sehingga karyawannya cakap dalam mengoperasikan program komputer keuangan yang digunakan dan mempunyai kepribadian yang baik serta mampu memberikan pelayanan yang maksimal kepada masyarakat.

\section{TELAAH LITERATUR DAN PERUMUSAN HIPOTESIS}

\section{Technology Acceptance Model (TAM)}

\section{Technology Acceptance Model} (TAM) menyatakan bahwa niat seseorang untuk menggunakan sistem atau teknologi ditentukan oleh dua faktor, yaitu persepsi kemanfaatan (perceived usefulness) yang didefinisikan sebagai tingkat di mana seseorang percaya bahwa penggunaan teknologi akan meningkatkan kinerjanya, dan persepsi kemudahan penggunaan (perceived ease of use) yang didefinisikan sebagai tingkat sejauh mana seseorang percaya bahwa penggunaan teknologi akan membuat dirinya bebas dari upaya atau lebih mudah dalam menyelesaikan suatu pekerjaan (Sayekti \& Putarta, 2016).

Penelitian ini menggunakan TAM untuk menjelaskan pengaruh computer anxiety dan internal locus of control yang mempengaruhi kinerja individual karyawan. Kinerja individual akan dapat ditingkatkan apabila masing-masing individu merasakan manfaat dan kemudahan dari penggunaan teknologi komputer dan akan berusaha menghilangkan kecemasannya dalam menghadapi perkembangan teknologi.

\section{Kinerja Karyawan}

Kinerja adalah hasil kerja baik secara kualitas maupun kuantitas yang dicapai oleh seseorang dalam melaksanakan tugas sesuai tanggung jawab yang diberikan (Juniariani et al., 2018). Kinerja individu adalah mengacu pada prestasi kerja individu yang diatur berdasarkan standar atau kriteria yang telah ditetapkan oleh suatu organisasi (Lindawati \& Salamah, 2011).

Kinerja karyawan sangat penting untuk diperhatikan karena kinerja karyawan sangat mempengaruhi keberhasilan suatu perusahaan. Kinerja dalam penelitian ini 
berhubungan dengan pencapaian serangkaian tugas-tugas oleh individu. Kinerja yang semakin tinggi melibatkan kombinasi dari peningkatan efisiensi, peningkatan efektivitas, peningkatan produktivitas dan peningkatan kualitas. Kinerja yang lebih baik akan tercapai jika individu dapat memenuhi kebutuhan individu dalam melaksanakan dan menyelesaikan tugas.

\section{Locus of Control}

Locus of control adalah sejauh mana seseorang percaya bahwa ia mampu mengendalikan faktor-faktor yang mempengaruhinya (Sanjiwani \& Wisadha, 2016). Individu yang memiliki kepercayaan terhadap dirinya sendiri dan menerima tanggung jawab atas segala tindakan yang dilakukan (internal locus of control) akan dapat meningkatkan kinerja individu tersebut (Saputra, 2012).

Locus of control merupakan salah satu sifat kepribadian yang dimiliki oleh seseorang. Locus of control dapat dibedakan menjadi dua yaitu locus of control internal dan locus of control eksternal. Locus of control internal merupakan kepercayaan seseorang akan kemampuan yang ada di dalam dirinya untuk mengendalikan keadaan. Sedangkan locus of control external adalah keyakinan individu bahwa apa yang terjadi dipengaruhi oleh faktor dari luar dirinya. (Sanjiwani \& Wisadha, 2016). Locus of control yang digunakan dalam penelitian ini adalah locus of control internal yaitu keyakinan diri yang dimiliki oleh masing-masing individu untuk meningkatkan kinerja mereka.

\section{Computer Anxiety}

Computer Anxiety dapat diartikan sebagai sifat individu yang mengalami kegelisahan, kecemasan terhadap penggunaan komputer. Komputer sebagai kecenderungan seseorang menjadi susah, khawatir dan ketakutan mengenai penggunaan teknologi informasi (computer) pada masa sekarang maupun pada masa yang akan datang (Naviera, 2015). Computer anxiety merupakan suatu bentuk kompleksitas yang terjadi karena ketidaksesuaian kerja dengan kemampuan personal computer (PC) serta tidak adanya konsekuensi jangka panjang yang mempengaruhi penggunaan komputer seperti peningkatan kualitas kerja, peningkatan karir, dan peningkatan keamanan kerja.

\section{Pengaruh Computer Anxiety terhadap Kinerja Karyawan Keuangan \\ Dalam teori Technology Acceptance Modal (TAM) menjelaskan}


tentang individu dalam menggunakan sistem teknologi informasi (Sayekti \& Putarta, 2016). Tidak semua individu menerima dengan positif perkembangan teknologi komputer. Kecemasan dalam menggunakan komputer (computer anxiety) akan mempengaruhi kinerja individual karyawan. Computer anxiety adalah sifat individu yang mengalami kegelisahan atau kecemasan terhadap adanya komputer. Computer anxiety dapat didefinisikan sebagai kecenderungan seseorang menjadi susah, khawatir atau ketakutan mengenai penggunaan teknologi (komputer) pada masa yang sekarang atau pada masa yang akan datang (Yudha \& Ramantha, 2014). Dengan adanya kondisi tersebut tentu akan sangat merugikan perusahaan tempat karyawan tersebut bekerja (Wahyudi \& Widianto, 2019).

Computer anxiety berpengaruh negatif terhadap keahlian kinerja karyawan keuangan dalam mengoperasikan program komputer keuangan. Hal ini berarti apabila seseorang memiliki computer anxiety yang rendah, maka seseorang tersebut cenderung akan memiliki keahlian yang tinggi. Artinya semakin tinggi kecemasan seseorang terhadap komputer maka semakin rendah kinerja seseorang tersebut. Berdasarkan uraian tersebut maka dapat dirumuskan hipotesis sebagai berikut:
$\mathrm{H}_{1}$ : Computer anxiety berpengaruh negatif terhadap kinerja karyawan keuangan.

\section{Peran Moderasi Internal Locus of Control pada Hubungan Computer Anxiety dan Kinerja Karyawan Keuangan}

Locus of control terkait dengan tingkat kepercayaan seseorang tentang peristiwa, nasib, keberuntungan dan takdir yang terjadi pada dirinya, apakah karena faktor internal atau faktor eksternal. Locus of control individu memainkan peran penting dalam menumbuhkembangkan motivasi individu guna meningkatkan kinerjanya. Individu yang memiliki kepercayaan terhadap dirinya sendiri dan menerima tanggung jawab atas segala tindakan yang dilakukan (internal locus of control) akan dapat meningkatkan kinerja individu tersebut (Saputra, 2012). Individu dengan sifat kepribadian ini cenderung mampu menumbuhkan motivasi dalam dirinya untuk mencapai suatu prestasi salah satunya adalah meningkatkan kinerjanya. Karyawan keuangan dengan kecenderungan internal locus of control akan memiliki keyakinan yang tinggi pada kemampuannya 
dalam mengoperasikan program komputer keuangan sehingga kecemasannya dalam mengoperasikan komputer (computer anxiety) dapat diatasi dan akan mampu meningkatkan kinerjanya.

Harimurti dan Astuti (2016) menyatakan bahwa internal locus of control memoderasi pengaruh computer anxiety dalam penggunaan software akuntansi terhadap keahlian pemakai komputer pada. Interaksi antara kecemasan berkomputer dengan internal locus of control akan meningkatkan keahlian individu dalam menggunakan komputer. Berdasarkan uraian tersebut adapun rumusan hipotesis yang dapat dibangun adalah sebagai berikut:

$\mathrm{H}_{2}$ : Internal locus of control memoderasi hubungan computer anxiety dengan kinerja karyawan keuangan.

\section{METODE}

\section{Rancangan Penelitian}

Penelitian ini merupakan penelitian kuantitatif dan dilakukan pada LPD yang terdapat di Kota Denpasar. Jumlah LPD yang berada di Kota Denpasar adalah sebanyak 35 (tiga puluh lima) yang tersebar di 4 kecamatan yaitu Denpasar Selatan, Denpasar Utara, Denpasar Timur, Denpasar Barat.

\section{Populasi dan Sampel}

Jumlah populasi sebanyak 524 orang pegawai yang bekerja di 35 LPD yang tersebar di Kota Denpasar. 35 Lembaga Perkreditan Desa tersebut tersebar di 4 (empat) kecamatan yaitu sebanyak 10 (sepuluh) LPD di Kecamatan Denpasar Utara, 12 (dua belas) LPD di Kecamatan Denpasar Timur, 11 (sebelas) LPD di Kecamatan Denpasar Selatan dan 2 (dua) LPD di Kecamatan Denpasar Barat. Penyampelan atas responden dilakukan dengan metode purposive sampling, dengan ketentuan bahwa karyawan tersebut mengoperasikan komputer keuangan yaitu bendahara, kasir, bagian dana dan bagian kredit. Berdasarkan hal tersebut jumlah sampel yang digunakan dapat dilihat pada Tabel 1.

\section{Variabel Penelitian}

Variabel yang digunakan dalam penelitian ini adalah variabel independen (X) dan variabel dependen (Y). Variabel independen yaitu computer anxiety Variabel dependennya adalah kinerja karyawan keuangan (Y) dan variabel moderatornya adalah internal locus of control. Penilaian dilakukan dengan beberapa pertanyaan menggunakan skala likert dengan pemberian skor 1 untuk pilihan Sangat Tidak Setuju (STS), skor 2 untuk pilihan Tidak 
Tabel 1. Kriteria Pemilihan Sampel

\begin{tabular}{clc}
\hline No & \multicolumn{1}{c}{ Keterangan } & $\begin{array}{c}\text { Jumlah } \\
\text { Responden }\end{array}$ \\
\hline 1 & Jumlah Karyawan di seluruh LPD Kota Denpasar & 524 \\
2 & $\begin{array}{l}\text { Jumlah Karyawan yang tidak mengoperasikan program keuangan } \\
\text { (sekretaris, marketing, kolektor, Cleaning Service \& satpam) }\end{array}$ & 325 \\
3 & Jumlah Karyawan yang digunakan sebagai sampel & 199 \\
\hline
\end{tabular}

Setuju (TS), skor 3 untuk pilihan netral (N), skor 4 untuk pilihan Setuju (S) dan skor 5 untuk pilihan Sangat Setuju (SS).

\section{Computer Anxiety}

Computer anxiety sebagai kecenderungan seseorang menjadi susah, khawatir atau ketakutan mengenai penggunakan teknologi informasi (komputer) pada masa sekarang atau masa yang akan datang. Dalam penelitian ini alat ukur yang digunakan adalah instrumen CARS (Computer Anxiety Rating Scale). Adapun indikator yang digunakan adalah fear (takut) atau ketakutan terhadap komputer, dan anticipation (antisipasi) atau hal-hal yang berkaitan dengan cara mengatasi kegelisahan terhadap komputer.

Internal Locus of Control

Internal locus of control merupakan individu dengan keyakinan bahwa jika mereka bekerja keras mereka akan berhasil, dan percaya bahwa orang yang gagal adalah karena kurangnya kemampuan atau motivasi. Pengukuran sikap keperibadian ini menggunakan Work Locus of Control Scale (WLCS) yaitu percaya pada kemampuan diri sendiri dan percaya pada hasil usaha (sukses).

\section{Kinerja Karyawan Keuangan}

Kinerja karyawan yang dimaksud pada penelitian ini adalah kinerja karyawan keuangan. Kinerja karyawan adalah pencapaian atau tingkat keberhasilan seseorang secara keseluruhan selama periode tertentu di dalam melaksanakan tugas dibandingkan dengan kemungkinan, seperti standar hasil kerja, target atau kriteria yang telah yang telah ditentukan terlebih dahulu dan telah disepakati bersama. Indikator yang digunakan untuk mengukur variabel ini adalah kuantitas hasil kerja, kualitas hasil kerja dan ketepatan waktu penyelesaian pekerjaan. 
Tabel 2. Analisis Statistik Deskriptif

\begin{tabular}{lccccc}
\hline \multicolumn{1}{c}{ Variabel } & $\mathrm{N}$ & Minimum & Maximum & Mean & Std. Deviation \\
\hline Computer anxiety (X1) & 108 & 25,00 & 35,00 & 30,367 & 3,038 \\
Internal locus of control (X2) & 108 & 41,00 & 55,00 & 48,653 & 4,516 \\
Kinerja Karyawan (Y) & 108 & 21,00 & 56,00 & 40,551 & 8,562 \\
Valid N (listwise) & 108 & & & & \\
\hline
\end{tabular}

Sumber: Data diolah

\section{Analisis Data}

Data yang digunakan dalam penelitian ini adalah data primer yaitu data yang diperoleh langsung dari sumber asli (tidak melalui media perantara) yang secara khusus dikumpulkan oleh peneliti untuk menjawab penelitian (Ghozali, 2012). Data primer dalam penelitian ini, yaitu jawaban responden atas pertanyaan-pertanyaan dalam kuesioner penelitian yang dikumpulkan dengan menggunakan metode survei. Teknik analisis yang digunakan dalam penelitian ini Moderated Regression Analysis (MRA), karena penelitian ini ingin menguji interaksi antara dua variabel utama serta sebuah variabel moderasi.

\section{HASIL DAN PEMBAHASAN}

Data dari penelitian ini dikumpulkan menggunakan kuesiner yang diberikan kepada karyawan LPD di Kota Denpasar. Dari 199 kuesioner yang disebar, 63 kuesioner tidak lengkap dan 28 kuesioner tidak kembali. Sehingga hanya 108 kuesioner yang dapat digunakan.

\section{Statistika Deskriptif}

Hasil statistika deskriptif terhadap variabel penelitian yaitu disajikan pada tabel 2. Variabel Computer anxiety (X1) memiliki nilai maksimum sebesar 35. Nilai rata-rata sebesar 30,37 menunjukkan secara rata-rata jawaban responden cenderung mengarah ke nilai tertinggi, artinya sebagian besar karyawan keuangan LPD di kota Denpasar memiliki anxiety yang relatif tinggi.

Sementara itu, variabel Internal locus of control (X2) memiliki nilai maksimum sebesar 55,00. Nilai ratarata sebesar 48,65 menunjukkan secara rata-rata jawaban responden cenderung mengarah ke nilai tertinggi, artinya sebagian besar karyawan keuangan LPD di Kota Denpasar memiliki internal locus of control yang relatif tinggi. Variabel kinerja karyawan keuangan (Y) adalah 
memiliki nilai maksimum sebesar 56,00. Nilai rata-rata sebesar 40,551 menunjukkan secara rata-rata jawaban responden cenderung mengarah ke nilai tertinggi, artinya sebagian besar karyawan keuangan di LPD Kota Denpasar memiliki kinerja yang relatif baik.

\section{Uji Kualitas Data}

Berdasarkan pengujian validitas diketahui bahwa koefisien korelasi butir-butir pertanyaan dari semua variabel dalam kuesioner adalah valid, hal ini terlihat dari nilai pearson correlation dari masing-masing variabel memiliki nilai di atas 0,3. Berdasarkan pengujian reliabilitas diketahui bahwa variabel-variabel yang digunakan adalah relliabel, dapat dilihat dari nilai cronbach alpha dari setiap variabel memiliki nilai di atas 0,70 .

\section{Uji Asumsi Klasik}

Uji asumsi klasik terdiri dari uji normalitas, uji multikolonieritas dan uji heteroskedastisitas. Berdasarkan uji asumsi klasik diketahui bahwa semua variabel yang dipergunakan didalam penelitian ini berdistribusi normal dan terbebas dari masalah multikolonieritas serta heteroskedastisitas.

\section{Pengujian Hipotesis}

Teknik analisis yang digunakan dalam penelitian ini adalah analisis regresi moderasi. Hasil analisis regresi moderasi disajikan pada tabel 3. Sebelum model regresi digunakan untuk menguji hipotesis, maka terlebih dahulu dilihat kelayakan model regresi yang dapat dilihat melalui nilai signifikansi uji $F$ dan adjusted $\mathrm{R}^{2}$. Berdasarkan hasil regresi moderasi pada Tabel 3, Uji F-test dengan uji Anova, diperoleh tingkat signifikansi sebesar 0,000 lebih kecil dari $a=0,05$. Nilai tingkat signifikansi tersebut menunjukkan bahwa model persamaan regresi dalam penelitian ini layak untuk digunakan.

Dapat dilihat pada kolom Adjusted $R$ Square di Tabel 3 menunjukkan nilai 0,760. Hal ini menunjukkan bahwa variabelvariabel independen memberikan kontribusi sebesar 0,760 atau $76 \%$ terhadap variabel dependennya. Sedangkan sisanya sebesar 24\% dipengaruhi oleh variabel lain yang tidak terdapat dalam model persamaan regresi yang digunakan dalam penelitian ini.

Berdasarkan hasil uji $t$ pada Tabel 3 yang merupakan pengujian hipotesis maka dapat dijelaskan pengaruh masing-masing variabel, serta menjawab hipotesis penelitian yang telah dirumuskan sebelumnya. 
Tabel 3. Hasil Analisis Regresi Linear Moderasi

\begin{tabular}{lccccc}
\hline \multirow{2}{*}{ Variabel } & \multicolumn{2}{c}{$\begin{array}{c}\text { Unstandardized } \\
\text { Coefficient }\end{array}$} & $\begin{array}{c}\text { Standardized } \\
\text { Coefficient }\end{array}$ & $t$ & Sig \\
\cline { 2 - 4 } & \multicolumn{2}{c}{ Std. Error } & Beta & & \\
\hline Constant & 0,575 & 0,909 & & 1,620 & 0,036 \\
X1 & $-0,232$ & 0,031 & 0,387 & 7,401 & 0,000 \\
X2 & 0,689 & 0,151 & 0,604 & 4,555 & 0,000 \\
X1_X2 & $-0,025$ & 0,006 & $-0,090$ & $-0,375$ & 0,030 \\
R & $: 0,837$ & & & & \\
R Square & $: 0,875$ & & & & \\
Adjusted R ${ }^{2}$ & $: 0,760$ & & & & \\
F hitung & $: 196,736$ & & & & \\
Sig. & $: 0,000$ & & & & \\
\hline Sumber: data diolah & & & & \\
\hline
\end{tabular}

Pengujian dilakukan dengan menggunakan tingkat signifikansi 5\% $(0,05)$.

Pengaruh Computer Anxiety terjadap Kinerja Karyawan Keuangan.

Hipotesis pertama menyatakan bahwa computer anxiety berpengaruh negatif pada kinerja karyawan keuangan. Berdasarkan Tabel 3, dapat dilihat bahwa hasil uji $t$ terhadap variabel computer anxiety $\left(\mathrm{X}_{1}\right)$ diperoleh nilai signifikansi $\mathrm{t}$ sebesar 0,000 dan nilai koefisien regresi (B) positif - 0,232. Nilai signifikansi computer anxiety sebesar $0,000<0,05$ maka $\mathrm{H}_{1}$ diterima. Hal ini berarti computer anxiety berpengaruh negatif pada kinerja karyawan keuangan.
Hal ini menunjukkan bahwa semakin tinggi computer anxiety yang dirasakan maka kinerja karyawan akan semakin menurun atau sebaliknya semakin rendah computer anxiety yang dirasakan maka kinerja karyawan akan semakin bagus. Kecemasan dalam menggunakan komputer akan sangat mempengaruhi kinerja karyawan dan tentunya juga akan berdampak bagi perusahaan. Karyawan yang mengoperasikan program keuangan pada LPD harus mampu menghilangkan kecemasan terhadap komputer yang mereka rasakan. Kecemasan tersebut akan membuat mereka tidak mampu mengoperasikan program keuangan yang digunakan oleh LPD dengan baik. Terdapat kemungkinan kesalahan pencatatan yang akan 
mereka lakukan akibat dari computer anxiety dan kesalahan tersebut tentu akan mempengaruhi kinerja LPD. Karyawan yang mengoperasikan program keuangan harusnya bekerja dengan teliti karena laporan yang dihasilkan dari program keuangan tersebut akan digunakan sebagai informasi oleh pihak internal maupun pihak ekternal LPD dalam mengambil keputusan.

Hasil penelitian ini sejalan dengan penelitian yang dilakukan oleh Yudha \& Ramantha (2014) serta penelitian Wahyudi \& Widianto (2019) yang membuktikan bahwa computer anxiety berpengaruh negatif terhadap kinerja karyawan.

\section{Pembahasan Hasil Penelitian}

Pengaruh Moderasi Internal Locus of Control terhadap Hubungan Computer Anxiety dengan Kinerja Karyawan Keuangan.

Hipotesis kedua menyatakan bahwa internal locus of control memoderasi pengaruh computer anxiety pada kinerja karyawan keuangan. Berdasarkan Tabel 3, dapat dilihat bahwa hasil koefisien interaksi variabel computer anxiety $\left(\mathrm{X}_{1}\right)$ dan internal locus of control $\left(\mathrm{X}_{2}\right)$ diperoleh nilai signifikansi $\mathrm{t}$ sebesar 0,030 dan nilai koefisien regresi (B) positif -0,025. Nilai signifikansi sebesar $0,030<0,05$ maka $\mathrm{H}_{2}$ diterima. Hal ini berarti internal locus of control memperlemah pengaruh computer anxiety pada kinerja karyawan keuangan.

Hal ini menunjukkan bahwa individu dengan kecenderungan internal locus of control akan memiliki keyakinan yang tinggi pada kemampuannya dalam hal ini menggunakan program komputer keuangan sehingga kecemasannya dalam mengoperasikan komputer (computer anxiety) dapat diatasi dan kinerjanya akan semakin meningkat. Individu dengan sifat kepribadian ini cenderung mampu menumbuhkan motivasi dalam dirinya untuk mencapai suatu prestasi salah satunya adalah meningkatkan kinerjanya. Karyawan LPD yang mengoperasikan program keuangan perlu memiliki internal locus of control yang tinggi karena dalam melaksanakan pekerjaannya dibutuhkan ketelitian dan konsentrasi yang lebih agar tidak terjadi kesalahan dalam mengoperasikan program keuangan tersebut.

Hasil penelitian ini sejalan dengan Harimurti dan Astuti (2016) dalam penelitiannya yang menyatakan bahwa internal locus of control memoderasi pengaruh computer anxiety dalam penggunaan software akuntansi terhadap keahlian 
pemakai komputer pada mahasiswa. Interaksi antara kecemasan berkomputer dengan internal locus of control akan meningkatkan keahlian mahasiswa dalam menggunakan komputer.

\section{KESIMPULAN, IMPLIKASI DAN KETERBATASAN PENELITIAN}

Dari data yang didapatkan, analisis data yang dilakukan, dan pembahasan dalam penelitian ini, maka kesimpulan dari penelitian ini adalah computer anxiety berpengaruh negatif terhadap kinerja karyawan keuangan LPD di Kota Denpasar. Semakin tinggi computer anxiety yang dirasakan seseorang maka kinerja karyawan akan semakin menurun.

Internal locus of control memoderasi hubungan computer anxiety dengan kinerja karyawan keuangan LPD di Kota Denpasar. Individu dengan kecenderungan internal locus of control akan memiliki keyakinan yang tinggi pada kemampuannya dalam hal ini menggunakan program komputer sehingga kecemasannya dalam mengoperasikan komputer (computer anxiety) dapat diatasi dan kinerjanya akan semakin meningkat.

Saran yang dapat diberikan untuk pengembangan dari hasil penelitian ini adalah bagi praktisi khususnya karyawan LPD Kota
Denpasar agar menjadi masukan bahwa sikap kecemasan berkomputer (computer anxiety) akan menurunkan kualitas kinerja. LPD perlu memberikan pelatihan program komputer akuntansi dan pelatihan kepribadian secara rutin kepada karyawan agar mereka bisa mengikuti perkembangan teknologi dan bisa memberikan pelayanan yang maksimal kepada masyarakat. Dalam proses perekrutan karyawan di masa mendatang agar melakukan pengujian internal locus of control sebagai input dalam mengevaluasi apakah akan menerima atau menolak karyawan yang mengajukan lamaran sebagai karyawan LPD.

Untuk penelitian selanjutnya dapat menambahkan variabel independen lain yang mempengaruhi kinerja karyawan serta menambah sampel penelitian agar lebih beragam dan hasilnya dapat digeneralisasi.

\section{REFERENSI}

Ali, S., \& Fadila. (2008). Kecemasan Berkomputer (Computer Anxiety) dan Karakteristik Tipe Kepribadian pada Mahasiswa Akuntansi. Simposium Nasional Akuntansi (SNA) Ke- 11, 1-35.

Ghozali, I. (2012). Aplikasi Analisis Multivariate dengan Program IBM SPSS 20 (6th ed.). Semarang: Badan Penerbit Universitas Diponegoro.

Harimurti, F., \& Astuti, D. S. P. (2016). Pengaruh Computer 
Anxiety terhadap Keahlian Pemakai Komputer dengan Internal Locus Of Control sebagai Variabel Moderasi. Jurnal Ilmiah Akuntansi Dan Bisnis, 11(2), 9199.

https://doi.org/10.24843/jiab.20 16.v11.i02.p04

Juniariani, N. M. R., Pradnyanitasari, P. D., \& Priliandani, N. M. I. (2018). Kinerja Individual Karyawan Ditinjau dari Konsep Theory of Planned Behavior (Studi Kasus pada Dinas Perpustakaan dan Kearsipan Kota Denpasar). Behavioral Accounting Journal, 1(1), 25-36. https://doi.org/10.33005/baj.v1i 1.16

Lindawati, H., \& Salamah, I. (2011). Pemanfaatan Sistem Informasi dan Teknologi Informasi Pengaruhnya terhadap Kinerja Individual Karyawan. Jurnal Akuntansi Dan Keuangan, 14(1), 56-68.

https://doi.org/10.9744/jak.14.1 .56-68

Naviera, W. (2015). Pengaruh Computer Self-Efficacy, Computer Anxiety dan Attitude pada System Use dan Dampaknya terhadap User Satisfaction dan Individual Impact (Studi pada Mahasiswa Program Sarjana Angkatan 20112013 sebagai Pengguna Sistem Informasi Akademik Mahasiswa (SI. Profit: Jurnal Administrasi Dan Bisnis, 9(2), 1-11. https://doi.org/10.21776/ub.pro fit.2017.011.01.2

Parasara, A. A. P. (2014). Pengaruh Computer Anxiety Pada Computer Self Efficacy. E-Jurnal Universitas Udayana, 7(2), 289298.

Patria, I. K. R. (2019). Pemkot Menargetkan Seluruh LPD seKota Denpasar Memiliki Server
Tahun 2022. Retrieved March 3, 2020, from https:/ / www.news.beritabali.com $/ \mathrm{read} / 2019 / 01 / 30 / 2019013000$ $17 /$ pemkot-menargetkanseluruh-lpd-se-kota-denpasarmemiliki-server-tahun-2022/

Sanjiwani, D. P., \& Wisadha, I. G. S. (2016). Pengaruh Locus of Control, Gaya Kepemimpinan dan Komitmen Organisasi pada Kinerja Auditor Kantor Akuntan Publik. E-Jurnal Akuntansi, 14(2), 920-947.

Saputra, K. A. K. (2012). Pengaruh Locus of Control terhadap Kinerja Internal Auditor dengan Kultur Lokal Tri Hita Karana sebagai Variabel Pemoderasi. Jurnal Akuntansi Multiparadigma, 3(1), 86-100.

Saputra, K. A. K., \& Kurniawan, P. S. (2017). Konsep Good Corporate Governance dan Fungsi Badan Pengawas Sebagai Internal Auditor LPD di Bali. Simposium Nasional Akuntansi XX.

Saputra, K. A. K., Sujana, E., \& Tama, G. M. (2018). Perspektif Budaya Lokal Tri Hita Karana dalam Pencegahan Kecurangan pada Pengelolaan Dana Desa. Jurnal Akuntansi Publik, 1(1), 28-41. https://doi.org/10.32554/jap.v1. i1.p28-41

Sayekti, F., \& Putarta, P. (2016). Penerapan Technology Acceptance Model (TAM) dalam Pengujian Model Penerimaan Sistem Informasi Keuangan Daerah. Jurnal Manajemen Teori Dan Terapan, 9(3), 196-209. https://doi.org/10.20473/jmtt.v 9i3.3075

Wahyudi, W., \& Widianto, T. (2019). Pengaruh Computer Anxiety dan Computer Attitude terhadap Keahlian Pengguna Komputer. AKTIVA: Jurnal Akuntansi Dan 
JIA (Jurnal Imiah Akuntansi) • Vol. 5, No. 1, hal: 45-60 • Juni 2020

Investasi, 4(2), 165-176.

Yudha, C. K., \& Ramantha, I. W. (2014). Pengaruh Computer
Anxiety dan Computer Attitude pada Keahlian Pengguna dalam Menggunakan Komputer. EJurnal Akuntansi, 9(3), 644-657. 